\title{
A Power Paradox: Growth of the Hydro Sector in Nepal
}

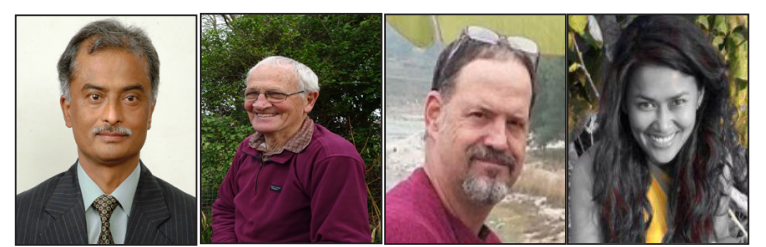

Ratna Sansar Shrestha Stephen Biggs

\section{Ratna Sansar Shrestha, Stephen Biggs, Scott Justice and Amanda Manandhar Gurung}

Abstract: Nepal has tremendous hydropower potential yet paradoxically experiences, until recently, loadshedding of up to 18 hours daily in the dry season and has not achieved self-reliant energy security. This paper analyses this paradox by reviewing the growth of hydroelectricity sector in Nepal. It identifies four phases; the illustration of technical capacity, industrial training and early investments, major policy challenges and paradigm shift and maturing hydropower sector.The spread of improved water mills as well as hydro installations is also reviewed briefly. The paper argues that Nepal will meet much of its projected national demand very soon (2018/19) but attaining self-reliant energy security after displacing fossil fuel is not in the horizon yet. While substantial hydro investments are in the pipeline; a strong, diverse hydro-mechanical manufacturing industry is established.But the electro-mechanical industry is non-existent. Policies have attracted substantial private investment in hydropower sector, but it is not geared towards the use of electricity for overall economic development of Nepal and has yet to streamline policy with respect to lean season augmented flow of water for drinking and irrigation purposes within and outside Nepal. A more fundamental paradox is that Nepal government has yet to acknowledge these anomalies that hinder sustainable economic developments.

Keywords: Hydroelectricity, capital goods, policy, Nepal

\section{Introduction}

66 7 The perennial electricity shortage, against a continuously rising demand within the country, has given birth to a power paradox of unrealized potential," (The Rising Nepal, November 2014), is a statement that reflects the contradictory situation present in Nepal; a country so endowed with hydropower potential, suffers until recently, from regular power cuts for upto 18 hours a day ${ }^{1}$.

As of 2011, about $63 \%$ of Nepalese households lacked access to electricity ${ }^{2}$ and, paradoxically, loadsheddingis limited to areas that have access to the electricity. Nepal is dependent on imported fossil fuel (coal and petroleum products including LPG) constituting $16.68 \%$ of the sources of energy, while electricity constitutes only 3.32\% (GoN, 2017). Similarly, renewable (microhydro, solar, wind, biogas, improved cook stove, etc.) constitute $3.03 \%$. But dependency on traditional sources, such as biomass and animal/agro-residue, is a massive $76.9 \%$. The concept of self-reliant energy security has three dimensions: (i) to make electricity accessible/available to all, not only for household use but also for power industries, agricultural and other activities in Nepal; ii) to drastically displace imported fossil fuel with hydropower, resulting in it becoming the source for $23 \%$ of the energy mix ${ }^{3}$, iii) to move rural households away from traditional sources of energy.

Hydropower, manifesting the connection between water and energy, is not limited to Nepal, a sentiment illustrated by Gies": "This water-energy nexus has been coming into focus over the last couple years. The idea is that water and energy are inextricably linked: it takes water to make energy and energy to clean and move water". But a recent article even deconstructs nexus debates, arguing that although "it is difficult to disagree with a vision of integration between water, food and energy systems", not only is there little consensus about what it means in reality, as the "idea of 'the nexus' has been put forward by a range of proponents - each with his or her own perspectives and agendas", but also, these debates "mask a bigger debate on resource inequality and access, contributing to social instability ${ }^{5}$ ". In Nepal, an activists' group advocated to make the Melamchi drinking water scheme multipurpose - to avail 1,000 Million Litres Per Day (MLPD) additional drinking water for Kathmandu instead of just the envisioned 170 MLPD, to generate $250 \mathrm{MW}$ hydropower, to rejuvenate the Bagmati River and to ensure water availability for irrigation in 40,000 hectares in the Terai in the dry season in order to harness the water, food and energy nexus ${ }^{6}$. The group lobbied with several prime ministers, ministers and Parliamentary committees, with no results.

It is far beyond the scope of this paper to look at broader issues affecting water and energy policy at the national and regional level, however, we point to these policy arenas because decisions there determine the role different sizes of hydro units and distribution systems will play in future rural and broadly based economic development in Nepal. The scarcity of fresh water in the region for drinking, agricultural and industrial purposes also places renewed interest in Nepal's water catchment, holding and release policies ${ }^{7}$ with regard to its own economic development and supplies to downstream users within and outside Nepal. Climate change has also highlighted long-term policy issues concerning the use of Nepal's water resources as well as in other Himalayan countries ${ }^{8}$.

And finally, the blockade by India in 2015-2016 drastically reduced the availability of petroleum products and other commodities in Nepal, highlighting the dependence on fossil fuel from India and renewed interest in alternative/renewable sources of energy, 


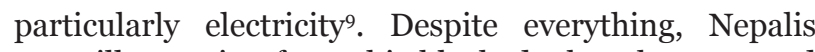
are still smarting from this blockade, but the state and even the public seems to be forgetting the lessons learnt from the blockade as no effort has been made towards self-sufficiency and switching of energy sources from imported to renewable generated in $\mathrm{Nepal}^{10}$. In a report prepared by the Nepal Oil Corporation (NOC), the demand for petroleum products is projected to increase by $500 \%$ in 15 years with $2014 / 15$ as base year ${ }^{11}$.

The water flowing in numerous rivers and rivulets give rise to Nepal's great natural assets, namely falling water to generate hydropower. Its history goes back hundreds of years ${ }^{12}$ with development of traditional Ghattas (water mill) that were traditional simple wooden-paddle water mills found along rivers and streams where the mechanical power (approximately 1-2 $\mathrm{kW}$ ) is used for grinding grain, hulling/husking paddy, oil production and even turning large Buddhist prayer wheels ${ }^{13}$. Bachmann ${ }^{14}$ tells the story where Engineer Akkal Man Narkarmi ${ }^{15}$ replaced the wooden parts with metallic ones, where the mill then becomes an "improved water mill" (IWM) and can generate electricity up to $3-5 \mathrm{~kW}$ (called pico hydro), sufficient for lighting and operating electric and electronic devices in isolated/ remote settlements.

Also in the late 1960 s with the introduction of cross flow turbines, microhydro ( $5 \mathrm{~kW}$ to $100 \mathrm{~kW})$ and mini hydro (100 kW to $1 \mathrm{MW}$ ) schemes began to flourish for milling and to provide access to electricity ${ }^{16}$ (The Alternative Energy Promotion Centre (AEPC) is involved in its promotion inter alia by providing subsidies ${ }^{17}$. Recent policy changes and accessible technology allows synchronous connection of mini hydro schemes to then ational grid, enabling such schemes to generate power 24-hours a day and supply to the local and national grid. Yet, generally electricity from pico and micro hydro schemes are not supplied to the grid mainly due to transmission $\operatorname{costs}^{18}$. Though the use of water for generating electricity in Nepal started in 1911, its development on a larger scale did not begin until the 1960s. Since then, Nepal's technical, human resources and even financial capacity for hydropower development has increased dramatically.

Dr HM Shrestha ${ }^{19}$ estimated in 1966 that Nepal has a theoretical hydropower potential of 83,000 MWof which 43,000 MW was found economically and technically feasible $^{20}$. The total hydropower capacity of the grid, operated by Nepal Electricity Authority (NEA), currently is $802 \mathrm{MW}$ installed capacity ${ }^{21}$. It is a paradox thus, that in a country endowed with so much potential, and a history of having the knowledge of hydropower for over 100 years, local demand for electricity from the national grid far exceeds the supply from the national grid at the current consumer tariff. This excess demand led to loadshedding of up to 18 hours a day in the country, particularly in the winter months when rivers are running low.

However, we suggest that presenting the energy paradox in this way is diverting attention from a more substantive paradox, which is: despite tremendous gains in local technical and institutional knowledge and even manufacturing in the hydropower arena, why is more positive recognition not given to the growing and strong hydro sector in Nepal? For at least the last ten years Nepal has even been exporting its hydro knowledge and complete systems to diverse places such as Afghanistan, India, Laos, Pakistan and Sri Lanka. This paper does not attempt to answer this question, but rather highlight it as the more important, yet unacknowledged paradox.

There has been no loadshedding in the capital ${ }^{22}$ since the beginning of 2017 and Government expects that enough hydropower will soon be produced nationally to meet Nepal's industrial and domestic demand, and its aim is to export 5,700 MW by 2021/22 23 (However, the end of loadshedding in Kathmandu was not achieved by the ample production of Nepali electricity. Instead, it was achieved by importing 400 MW electricity from India $^{24}$. Furthermore, a supplementary Power Purchase Agreement was signed with India's NTPC Vidyut Vyapar Nigam (NVVN) on May 27, 2017 to import an additional $160 \mathrm{MW}^{25}$ (cumulative $560 \mathrm{MW}$ ). The installed capacity in NEA's system is around 800 MW, generating a little over one-third of that in the dry season. Thus, although loadshedding stands "mitigated", Nepal is not energy secure, nor self-reliant. Current crude estimates for electricity required "for normal economic growth scenario of Nepal is more than 6,000 MW" to achieve self-reliant energy security ${ }^{26}$ Ensuring availability of electricity for the entire population would require 2,700 MW under the business as usual scenario. Additionally, Nepali industries have 700 MW of standby generators and would need nearly $1,000 \mathrm{MW}$ more to operate at full capacity; it would take an additional 1,00o MW to displace LPG from kitchens; $500 \mathrm{MW}$ would be needed to electrify transportation; and $700 \mathrm{MW}^{27}$ to displace diesel irrigation pumps in the Terai ${ }^{28}$. In this backdrop, if Nepal exports power without meeting her own demand (both unmet and latent) to saturation level, it will amount to a paradox within a paradox; continuing to import fossil fuel while exporting hydropower.

The strong diverse hydro sector has grown and developed substantial technical capabilities for manufacture of hydro-mechanical with backstopping capabilities to negotiate with aid agencies and the corporate sector, including for energy, water policies and projects. But Nepal is not capable to negotiate with powerful neighbours, manifested in treaties signed with India to date and the multiple agreements signed with developers for export-oriented projects ${ }^{29}$. In light of this background, we review the history of hydropower development in Nepal and suggest four phases:

1) Technical capability illustrated,

2) Substantial industrial training and early hydro investments,

3) Major challenges in policy and paradigm shift, and

4) Maturing hydro energy sector and technology game change.

\section{Methodology}

The main method was literature review of many secondary sources and personal experience of working in the industry ${ }^{30}$. This includes published and grey 
documents from government agencies, such as National Planning Commission (NPC), Ministry of Energy, Water Resources, and Irrigation (MoEWRI), Water and Energy Commission Secretariat (WECS), Investment Board of Nepal (IBN), NEA, AEPC, NOC, various commissions, task force and donor projects ${ }^{31}$. Unravelling data from government and donor projects was particularly challenging as often projects reported on their own activities, with little reference to national or other data that put the information into a broader national perspective. Local newspapers were reviewed, as in Nepal, many of the debates around hydropower are played out in the local press. Interviews were held with key informants in the industry such as local micro hydro users, manufacturers, contractors, equipment suppliers, private and community owners of equipment, members of trade organizations, relevant aid organizations and independent power producers. Major seminars were also attended. This research started with a focus on the spread of micro hydro for economic uses that significantly adds value to the economy in rural areas ${ }^{32}$ but was then extended to include small, medium, and large hydro in the endeavour to understand/analyse the paradox of abundant hydropower potential but failure to achieve self-reliant energy security and value addition in the macro economy. We have also taken a look at the growth of local hydro manufacturing and maintenance industries. Our analysis is still partial in so many ways, for example we have made no attempt to review overall energy policy in $\mathrm{Nepal}^{33}$. We have attempted to analyse the power paradox with energy security (also implying security of energy supply) as a backdrop (energy security defined as "the uninterrupted availability of energy sources at an affordable price") (IEA). Our focus is the availability of hydropower, because hydropower will and should play the dominant role in any future national energy policy of Nepal, reducing dependence on imported and subsidised fossil fuels. Although national tariff/pricing and subsidy policies are important issues relative to overall energy security, these are beyond the scope of this paper.

\section{Results and Discussion Classification}

The classification of hydropower is based on the installed capacity of the system. Based on conventional classification, system sunder $5 \mathrm{~kW}$ are pico hydro ${ }^{34}, 5$ to $100 \mathrm{~kW}$ micro hydro, $100 \mathrm{~kW}$ to $1 \mathrm{MW}$ mini hydro, 1 to 10 MW small hydro, 10 to $50 \mathrm{MW}$ medium hydro and above 50 MW large hydro ${ }^{3536}$.

\section{Critical issues}

The reasons for the lack of investment in larger-scale hydropower in Nepal are many and we do not attempt its analysis here. There are others who have looked at these issues in considerable depth ${ }^{37}$. However, we include a list of issues that repeatedly come into policy debates in Nepal concerning investment in large-scale schemes.

1. Whether to invest in hydropower for local economic development and domestic consumption or for export (hydro dollars) ${ }^{38}$ inter alia to mitigate the trade deficit. ${ }^{39}$

2. Powerful government 'hydrocrats' dominate policy debates and control advice from alternative sources of expertise.

3. Suspicions over the political or other motives of investors and consultants (including bilateral foreign governments).

4. The inter relatedness of hydropower considerations with multidimensional uses of Nepal's water resources especially for lean season augmented flow like water storage, groundwater replenishment, drinking water supplies, irrigation (most of which have regional implications) including flood control ${ }^{40}$.

5. The lack of diplomacy and negotiating capacities in Nepal, vis-à-vis dominant donors, and representatives of bordering and other countries in the region.

6. Memories and histories of fair and unfair development of past hydropower and water resources projects.

7. A lack of agreement on the frameworks and forecasting tools used to estimate financial, economic and social costs and benefits including positive and negative externalities and rates of return on hydro projects and large dams in general $^{41}$ including underdeveloped stage of discipline of financial engineering, which is not fully understood by most ${ }^{42}$.

8. The changing economic and technical environment for investment. For example, some hydro and water resources schemes are proposed and built using one ranking of national priorities to justify the scheme, while a few years later, another ranking of national priorities might be more relevant. In addition, once built, the actual use and outcomes of projects often changes over time ${ }^{43}$. This approach creates confusion amongst the project developers making them uncertain as to which project to be undertaken/implemented on which basis and when; thereby stunting the growth of the sector as a whole.

9. Changing composition of local and foreign investors ${ }^{44}$.

10. Degree of public and private ownership in different parts (generation, distribution, transmission and use) of the hydropower sector (bundling and unbundling).

11. Balance of run of the river and storage projects ${ }^{45}$.

As we discuss at the end of the paper, the growth and maturing of the hydro sector has given rise to a diverse, sustainable industry where loadshedding of the type experienced in recent years should be over if policy and its implementation is properly geared to meet Nepal's own demand and ensure self-reliant energy security. The planned commissioning of the 456 MW Upper Tamakoshi project in April 2019 (after a two-year delay due to earthquake and Indian blockade) ${ }^{46}$ will be a significant major step in that direction for supplying the national grid $^{47}$.

\section{Phases in the Development of the Nepal's Hydropower Industry}

Technical capability illustrated (1911-early 1960s)

Perhaps the most well-known example of a mini hydro is the $500 \mathrm{~kW}$ Pharping Powerhouse established by the Rana rulers of Nepal in 1911 AD, a gift from 
the British government to illuminate Rana palaces in Kathmandu and some streets. It generated electricity for 70 years until 1981 when the water was diverted to supply drinking water. It is owned by NEA and was rehabilitated in 2006. It is operated occasionally when water can be diverted from drinking water. There are now plans to turn it into a living museum ${ }^{48}$. The second oldest power station in Nepal is a $640 \mathrm{~kW}$ run of the river scheme in Sundarijal commissioned in 1935, about 24 years after Pharping. It has been running ever since and the water from its tailrace is supplied to the Kathmandu valley.

\section{Industrial training and early hydro investments (Mid 1960s-1990s)}

While the Pharping and Sundarijal plants illustrated well the feasibility and use of hydropower in Nepal, it was not until the mid-1960s that an interest in developing a hydropower manufacturing capability started.

The changes that have taken place in the industry since the 1970 are quite dramatic. One of the first examples of the development of hydropower for industrial use is the very well-known $1 \mathrm{MW}$ Tinau hydropower plant in Butwal. The project started with a $50 \mathrm{~kW}$ unit to replace the diesel generator and then developed into the $1 \mathrm{MW}$ system, a run of the river scheme with Francis turbine. It is important, not only for supplying electricity, but for its major role in the development of Nepal's hydropower industry. It was started in the mid-196os under the leadership of a Norwegian engineer Odd Hoftun ${ }^{49}$ and in 1972 operated by the BPC, which he incorporated. It was handed over to the NEA in 1980. Except for a time in the early 1980s when it was badly damaged by a flood, it has been in operation. Its construction was conceived not only to provide electricity to a nearby major Terai town, Butwal, but also to build up local skills and industrial capacities in the nascent hydropower industry. Odd Hoftun, supported by United Mission to Nepal (an international NGO), initiated the establishment of the Butwal Technical Institute (BTI) in 1963, which has been one of the major sources of hydro engineering training in Nepal. It now possesses a large industrial park, where many private companies are providing manufacturing and maintenance services for all sizes of operations in the hydropower industry.

By the late 1970s, the cross-flow turbines had become the most common microhydro turbine and two private companies, the Balaju Yantra Shala in Kathmandu and Development and Consulting Services (DCS) in Butwal ${ }^{50}$ played important roles in its development ${ }^{51}$. Odd Hoftun also established Nepal Hydro and Electric Co. (NHE) in Butwal in 1985 as a turbine workshop. It now specializes in fabrication/manufacture of hydro-mechanical equipment including High Voltage (HV) substations and repair and maintenance of electro-mechanical equipment for hydropower generation, transmission and distribution. Furthermore, the company has significant involvement in manufacture of heavy steel structures. Both the Butwal and Patan Industrial Estates were established many years ago and several of the micro hydro repair and manufacturer companies are located in these estates ${ }^{52}$. Several of these units have ISO 9001 certification, and some are moving into larger repair and manufacturing capabilities ${ }^{53}$.

A well-known example of a locally managed mini grid is at Namche Bazaar, the gateway to Mt. Everest. Its first project, started in 1976, was washed away by the Dig Tsho glacier lake outburst flood in 1985. A new run of river power plant, $630 \mathrm{~kW}$ installed capacity, with 2 double jet Pelton turbines ${ }^{54}$ was built on Thame Khola between 1988-1994 with Austrian Government assistance. The electricity has given light and power including for ICT to the locals, hotels and bakeries in both Namche ${ }^{55}$ and Khumjung VDCs including a local hospital.

\section{Major challenges to policy and paradigm shift (Early to Late 1990s)}

In 1991, Nepal's total installed capacity stood at 244 MW out of which $239 \mathrm{MW}$ was built and owned by NEA (including a 14.41 MW thermal power plant) and 5.1 MW hydro built with Norwegian government assistance and owned by BPC. ${ }^{6} 57$

1992 is a turning point in terms of the liberalization of the hydropower sector after the formulation of the Hydropower Development Policy58 (1992) and the promulgation of the Electricity Act, 1992 and Water Resource Act, 1992, liberalizing the sector to ensure hydropower development by attracting private sector investment in the 'build, own, operate and transfer' (BOOT) mechanism. Prior to this, the hydropower was in public domain ${ }^{59}$. In 1996, the AEPC was established, and in 1998 a set of policies that were favourable to the development of the smaller scale hydropower industry in Nepal was also introduced.

International donors and investors have also changed their behaviour significantly in 1990s and they are now far more open to a broader range of options, as regards to technology, management systems and investments plans in the electricity sector. Reflecting on the behaviour of donors in the mid-1990s, when civil society groups challenged, and stopped a proposed World Bank Arun 3 dam, Pandey notes: "Among the more than 40 conditionalities for donor investment into 'Baby Arun'60', the most problematic was: Outside the investment plan, NEA could not even study a hydropower project >10MW without donor approval ${ }^{61}$ ".

The debates around the $201 \mathrm{MW}$ Arun 3 confrontations illustrated well the issues involved. The disagreements at the time centred on the high per MW cost of the scheme, its environmental effects, the short and longterm distribution of benefits and costs - including effects on the growth of a local hydro industry. The debates on the pros and cons of the Arun 3 dam are still much alive and continue to influence national hydro energy policy debates and current negotiations on the development of hydro on the Arun River ${ }^{62}$. The debate was settled by the World Bank by refusing to fund it as IFC had, in the meantime, committed to fund 6o MW Khimti project, thereby rendering Arun 3 and Khimti projects mutually exclusive, due to negative covenant of Arun 3 project, proscribing undertaking project $>10 \mathrm{MW}$.

Similarly, with the establishment of AEPC and introduction of relevant policy, there was major support 
from international agencies for off grid hydro systems development as reflected through the programs of the $\mathrm{AEPC}^{63}$. Strong local business associations grew, like Nepal Micro Hydro Development Association (NMHDA) and Independent Power Producers' Association of Nepal (IPPAN) to lobby and promote their business interests.

Maturing hydro energy sector in new millennium (2000 - present)

The last one and a half decade has seen the maturing of the Nepal's hydropower sector. We look at this under three headings: supply, demand and institutions.

\section{- Electricity Supply: Nepal Hydropower Generation}

At the micro and mini hydro level, according to $\mathrm{AEPC}^{64}$ the total installed capacity, through till 2015/16 is 54.275 MW (AEPC, 2013). There is no reason to think that this off grid source of electricity will not continue to rise rapidly. Not only is this hydropower installed using Nepali expertise and equipment, but Nepali companies are now supplying and installing hydropower in many countries in the region.

At the macro level, under new policy allowing private investment in hydropower, $488 \mathrm{MW}$ was added to the system in 22 years from 1992 through till 2014 - double of what was built over eight decades. During this period (1992-2014), NEA added 238 MW (including 39 MW thermal power plant), whereas independent power producers (IPPs) implemented power projects totalling $250 \mathrm{MW}^{65}$. In 2016, total installed capacity in NEA system stood at $855.886 \mathrm{MW}$ (851.25 MW in the grid and $4.536 \mathrm{MW}$ isolated $)^{66}$. Of which NEA hydro is $477.9 \mathrm{MW}$ and thermal 53.4 MW. IPP hydro in the grid is 324.446 MW. Of 117 generation licenses issued for total installed capacity of 3,340.95 MW, 50 projects with total installed capacity of 324.446 MW have been commissioned through till $2015 / 16$, electricity from most of these is sold to NEA under power purchase agreements (PPAs) ${ }^{67}$. 91 IPP hydropower projects are under construction with 1,721 MW installed capacity ${ }^{68}$. Similarly, by November 30, 2016, the Department of Electricity Development (DoED) issued 276 survey licenses for various sizes of projects for 5,914 MW. Additionally, 159 licenses for survey of transmission lines and 63 licenses for construction of transmission lines have been issued through till July 2017.

It is projected that loadshedding in Nepal will come to an end, when the Upper Tamakoshi hydro plant (456 MW) is commissioneda long with smaller hydro plants such as the $50 \mathrm{MW}$ Upper Marshyangdi project ${ }^{69}$. After that, with forecasts of future investments in larger and smaller projects, certain segment of society believes that Nepal will not face major loadshedding for many years to come. But Nepal would still be very far from achieving self-reliant energy security that includes switching from fossil fuels used in households, transportation, and industries to hydropower. As regards large dams, negotiations have restarted with India on the 6,480 MW Pancheshwar project on the Mahakali River that separates the two countries on Nepal's western border. Yet, despite India's plans to develop it, eyeing stored water for large shortfalls in municipal, industry, and irrigation in North-Central India, the likelihood of its implementation is slim as India is coveting Nepal's share of water under the Mahakali Treaty ${ }^{70}$.

Till 1990s, supply was dominated by the NEA. But, of the total 562 MW from all projects completed since 1990s, only $42 \%$ came from the NEA, the rest was generated by the private sector. Of the total generated by private sector $34.7 \%$ includes foreign investment and $65.3 \%$ is Nepali investment only. There are now a very wide variety of Nepali investors, ranging from local institutional investors, such as Employees Provident Fund (EPF), Citizen Investment Trust (CIT) to commercial banks and special purpose companies and funds. There are also many Nepali construction companies that have grown steadily since the initial years of the training and hydro manufacturing initiatives in Butwal and Kathmandu in the mid-1970s ${ }^{71}$.

A relatively recent phenomenon is the emergence of Chinese suppliers in the Nepal market with inexpensive hydro technology both for micro ${ }^{72}$ (Forster undated) and macro hydro. Of 324 MW IPP hydropower plants in operation, Chinese suppliers account for close to 200 MW. NEA seems to prefer non-Chinese suppliers except in the Chamelia Project. Attraction of IPPs towards Chinese equipment primarily could be attributed to their competitive pricing. Only time will tell if the quality and performance of Chinese equipment is comparable to non-Chinese.

In terms of backward economic linkage benefits ${ }^{73}$ accruing to Nepal, it will not accrue till such equipment is manufactured/fabricated in Nepal. NHE and few other companies are capable to fabricate and supply most hydro-mechanical equipment, except for turbine runners. There are no electro-mechanical manufacturers of large generators in Nepal.

\section{- Electricity Demand}

The demand for electricity from the national grid has grown rapidly, especially during the last decade and itis fair to assume that it will continue to rise rapidly ${ }^{74}$. Unfortunately, Nepal lacks a dedicated institution tasked with responsibility to project future electricity demand, currently undertaken by NEA and WECS independently and jointly by NPC and Investment Board Nepal (IBN).

These three have come up with divergent figures for future electricity demand for 2030. According to a recent study conducted by NEA, the electricity demand (system peak load) in 2029/30 has been projected to be 4,280 MW. The WECS has projected electricity demand of $11,111 \mathrm{MW}$ in $2030^{76}$ based on Model for Analysis of Energy Demand (MAED), for reference scenario of $7.2 \%$ economic growth. The NPC and IBN's joint energy demand forecast for 2030, also based on the (MAED), is $10,092 \mathrm{MW}^{77}$. The latter two reports are based on studies that start out by using consumption of biomass, fossil fue land electricity as background but ends up projecting only electricity demand without regard to fuel switching to hydropower even after a few decades. Complete displacement of firewood, animal/agro-residue with 
clean energy has simply not been looked into, although due to indoor pollution these cause huge human tolls. In order to address the issue of this power paradox, Nepal needs a dedicated institution to prepare energy demand projections that aims to achieve self-reliant energy security with hydropower in every facet of household and industrial activities, and policy geared for government intervention to ensure the displacement of biomass and imported fossil fuel.

Electricity consumption in kilo Watt hours (kWh) per capita in Nepals tood at $128.1 \mathrm{kWh}$ per capita in 2013 according to the World Bank ${ }^{78}$. To put this into context, Malaysia with a similar population consumed 4,345 kWh per capita. Even states in India consume more - with Assam at $209 \mathrm{kWh}$, Manipur $207 \mathrm{kWh}$ and Uttar Pradesh at $387 \mathrm{kWh}$. In 2015-16, when the demand for electricity in Nepal was $1,385.3$ MW, NEA's installed capacity was only $855.9 \mathrm{MW}^{79}$ only, one third of which was generated in the dry season.

The excess of demand over supply has resulted in the extensive loadshedding in winter months ${ }^{80}$. While there are considerable losses of electricity due to faults and inefficiency in the national grid, even if these were greatly reduced there would still be excess demand over supply at existing tariff rates. Just how much electricity tariffs would have to rise so that supply meets demand is not often discussed in the Kathmandu press. This is partly because the electricity industry is a supply led industry. Preoccupation is with the supply of the service, with minimal concern with the management of demand. This is reflected by the normal method of reporting which is by electricity supplied (e.g. $\mathrm{xx} \mathrm{kW}$, or $\mathrm{xx} \mathrm{MW}$ ) or by the number of domestic households served (generally calculated by the average use of electricity for domestic purposes per household). This goes for both of the public-sector institutions concerned with electricity generation and the private sector. The demand for electricity by large and small industries is rarely part of public debates ${ }^{81}$. The spread of micro hydro under AEPC follows the supply approach of NEA and uses the number of households connected to the local mini grid as the main indicator of performance.

There is a presumption sometimes by domestic electricity consumers that it is their right to a source of electricity, either free, or at a low price. Under such a situation, when supply does not meet demand at prevailing tariffs rates, often a range of elite capture, corruption, rent seeking, and political patronage behaviour comes in. It is beyond the scope of this paper to discuss these issues, which are common in many countries. However, it is interesting to note that the first hydropower unit established in 1911 was used only for domestic lighting for the palaces of then Rana rulers. This differed from the early days of the $1960 / 70$ s in the improvement of local Ghattas, which were used for economic production purposes.

In recent years, concern with reducing 'leakages' in the system and the productive use of electricity has been reflected by the NEA selling electricity in bulk to community electrification entities ${ }^{82}$, which in turn retails to its consumer/members.
Paradoxically, the loadshedding of the last few years, and the recent Indian blockade has had advantages in regard to concentrating public discussion and in increasing awareness concerning the generation of electricity from national resources as well as the careful use of electricity. The large numbers of diesel and petrol generators of all sizes used during loadshedding and the blockade have not only been expensive, but have also changed perceptions concerning the supply, reliability and careful use of electricity for different purposes $^{83}$.

\section{Changes to Electricity Industry Public Sector Institutions}

Alongside the development of a robust, diversified Nepali electricity supply industry there have also been many changes in government regulations, trade agreements, procedures and institutions associated with public discourses. These changes can be illustrated by events in the late 2000 s and more recently.

Electricity Development Centre (EDC) was established in July 1993 under the then Ministry of Water Resources pursuant to Electricity Act, to develop and promote the hydropower sector by attracting private investment. This centre was also tasked with monitoring hydropower development work. It was renamed the Department of Electricity Development (DOED) in February $2000^{84}$. It is responsible for assisting the Ministry in implementation of overall government policies related to the power/electricity sector. The major functions of the DoED are to ensure transparency of the regulatory framework, promote and facilitate the private sector's participation in the power sector by providing "One Window" service and to issue licenses to hydropower projects and transmission and distribution networks; mainly to conduct feasibility studies and to construct the hydropower plants and to build the transmission and distribution network.

Electricity Tariff Fixation Commission (ETFC) was established in 1994 not as an independent/autonomous commission but to fix retail tariff. It has no jurisdiction over the bulk tariff at which NEA buys power from IPPs, nor has it the authority over import/export of power tariffs. With the promulgation of Nepal Electricity Regulatory Commission Act in 2017, a regulatory commission with comprehensive authority over the electricity sector will be constituted, which will supplant ETFC.

Power Transmission Company Nepal Limited (PTCNL) was registered in 2007 as a joint venture company with NEA owning 50\% equity, Nepal's Hydro electricity Investment and Development Co. Ltd (HIDCL) owning $14 \%$, India's Power Grid Corporation Limited 26\% and ILFS Energy Development Company Limited (IEDCL) $10 \%$. It is responsible for developing and executing the transmission system in Nepal in order to facilitate the cross-border power exchange between Nepal and India, evacuating power from export-oriented projects under construction in Nepal and to import power from India to mitigate loadshedding in Nepal. Under its ownership, a $42.1 \mathrm{~km}$ section of Dhalkebar-Muzaffarpur $400 \mathrm{kV}$ double circuit Transmission Line within Nepalese 
territory was successfully completed in February 2016.

Investment Board of Nepal (IBN) was established in 2011 "as a high-level fast track agency with the objective of facilitating the economic development of Nepal by creating an investment-friendly environment by mobilising and managing domestic as well as foreign investment" (Office of the Investment Board). In its early years it faced many challenges, including calls from the MoWRE for it to be disbanded in $2013^{85}$, essentially due to the conflict between the Electricity Act and Investment Board Act, 2010. Under the former, all electricity projects were under the jurisdiction of MoWRE. But the latter has put hydropower projects of capacity of $500 \mathrm{MW}$ or more under the purview of the IBN. The IBN has signed Project Development Agreements (PDAs) for the Upper Karnali (900 MW) project ${ }^{86}$ in September $2014^{87}$ and forthe Arun 3 (900 MW) project in November $2014^{88}$. It also has three other projects under preparation for negotiations that will generate a further 1,800 MW. Sadly, both of the projects for which IBN has already signed PDAs will not resolve the power paradox, as both of these projects are export oriented.

Power Trade Agreement (PTA); a second institutional change that raised electricity sector's profile is the signing of the Power Trade Agreement with India in $2014^{89}$. Electricity and water agreements with India have a very chequered history as has been documented elsewhere $^{90}$. However, what is significant about this new agreement is that it has come about within the context of a more open discourse in the public domain in Nepal. This reflects a far broader debate than in the past on the political nature of recognizing Nepal's water and electricity resource potential in the short, and possibly and more importantly, in the long term. This is especially important for the nation to understand that such export-oriented projects will not address the power paradox within Nepal. This is well illustrated by the caution and scepticism of some writers regarding the offer to Nepal by India of a US $\$ 1$ billion line of credit in August 2014 for hydro development. Some thought that should go towards the stalled joint India-Nepal program for Pancheshwar Multipurpose project. However, another three projects emerged from the past and led one observer to note, "whether they were truly born in Singha Durbar, or further away in Delhi ${ }^{11}$ " Whatever the next stages of these water and electricity negotiations, it is clear that there are now greater scrutiny of IndiaNepal government proposals, agreements and actions than in the past.

An important point that needs to be kept in mind is the fact that both Nepal and India are power deficit countries. Therefore, it is surprising how these two countries can trade in power, which they do not have, except during certain hours of the day or certain season $^{92}$. Moreover, if Nepal is to achieve self-reliant energy security, more power than it has potential from water resources is needed, thus obviating the prospect of exporting power from Nepal.

Electricity Generation Company (EGC) was established in 2016 with paid-up capital of Rs. 300 million and authorized capital of Rs. 20 billion. $30 \%$ of its equity is owned by various Ministries and public enterprises such as the NEA (10\%), EPF (10\%), Nepal Telecom (10\%), CIT (5\%), HIDC (4\%), Rastriya Beema Sansthan (2\%). $17 \%$ equity will be offered to general public, $10 \%$ to locals of districts affected by hydropower projects being developed by the company, $2 \%$ to highly impoverished people. Earlier, MoE had agreed in principle to award around 19 projects that are under the DoED's basket to this company.

Institutions of Public Discourse; a further dimension of the positive maturing of the electricity sector is the growth of journals, professional organizations, newspaper coverage and public dissent. Groups in Nepal's water and electricity sectors, for many years, had public debates on the direction and content of government and donor policies and practices - for example, the Arun 3 confrontation of the early 1990s. However, we suggest that this 'either/or' debate as some participants and observers portrayed it then, has now developed into a more mature debate where serious policy analysis is done and references to well established journals are made, such as Water Alternatives, reviews of books in Studies in Nepali History and Society (SINHAS) ${ }^{93}$ and HYDRO Nepal. The latter journal, which in the past had mainly articles focusing on technical issues, now has articles written also from legal, managerial, and socio-economic perspectives and empirically supported historical analysis concerning past negotiations and development ${ }^{94}$. Documents produced by consultants for influential donor organizations, are now less restricted than in the past, which is a healthy development and reflects also a growing maturity of aid organizations.

National Information Commission (NIC) was established in 2008 to implement the Right to Information (RTI) Act, the NIC is responsible for the protection, promotion and practice of RTI in Nepal. The NIC has played a positive role by issuing directives to the IBN to make the PDA signed for Upper Karnali Project public. In this manner, information of vital public interest has been put in the public domain and brought for public scrutiny and discourse. It is also a sign of maturity as the government was required to be transparent in its dealings in the matters of hydropower development, disallowing it to hide behind the shield of commercial deal.

Another sign of maturity of the electricity sector are the recent protests of locals and construction workers demanding a fair share of the planned benefits of hydro investment project. For example, the work of $456 \mathrm{MW}$ Upper Tamakoshi Hydropower Project was held up for some time, as the workers demanded more shares be allocated to them. In negotiations with the Nepal government, the Chairman of China's Three Gorges Corporation, proposed that the GoN implement the resettlement and rehabilitation of the estimated 20,000 people that would be displaced by the 750 MW West Seti Storage Hydropower project. GoN has not made any commitment in this respect as the project is yet to be implemented and no involuntary displacement has occurred $^{95}$. While policy level economic cost benefit analysis has generally underpinned government and donor policy decisions on dam investments, the 
selectivity and partial nature of the analysis, and whether compensations are paid is a notorious area of policy practice. The almost daily reporting in the local press on public and private projects and negotiating points concerning the hydropower sector reflects a healthy maturing of the electricity sector. Compared with only a few years ago, when powerful actors could make unsupported claims and promises and take actions, the current level of policy debates have become more technically and politically informed.

\section{Conclusions and Policy Implications}

This paper examines the Nepal power paradox. But we suggest there is a deeper paradox, namely the paradox that such a statement can be made, given the sustained development of the hydropower sector over the last few decades, and a level of policy debate in the public domain that could be an example to many other countries in the world. We reviewed the history of hydropower development in Nepal and suggested four phases in the growth of the sector.

\section{Policy Implications}

\section{Maintaining the momentum of technical and institutional change}

Perhaps the biggest policy challenge is the supply-led orientation of most analysts in the hydropower industry that has led to preoccupation with domestic use of electricity versus export, with minimal concern for broad based economic development and, importantly, attaining self-reliant energy security by displacing biomass and fossil fuel. This orientation has been found both in NEA and AEPC. Fortunately, with many new institutions opening up, the policy debates are changing. The diversity of investors in the hydropower sector has increased substantially. These are 'game changing' institutional and political changes that are leading to strong, diversified hydropower. The biggest challenge is to capitalize on the opportunities that are now opening.

Ramping up of technology has also favourably impacted two areas. The availability of inexpensive Chinese technology has made many commercial hydropower projects feasible. As more of such equipment is 'tested', there is likely to be easier and cheaper access to these ${ }^{96}$. The second area of technology change is growing likelihood of trans-Himalaya transmission lines ${ }^{97}$. A decade ago the Himalayas were thought to be impenetrable for such energy trade. Yet, on a visit by the Nepali Prime Minister to China in March 2016, a joint communiqué was released where "China is to provide technical and financial supports to conduct feasibility study ... to develop Arun Kimathanka Hydropower Project (434 MW) and build a $400 \mathrm{kV}$ trans-border transmission line that supports exchange of up to 1500 MW via Rasuwagadhi-Kerung route", which is currently being upgraded to become Nepal and China's preferred overland trade route and where, in other reports, China is proposing to link Kathmandu by rail ${ }^{98}$. If such projects prove to be economically feasible, then Nepal doubles thelist of energy buyers, including to power such rail links.
Treating hydro manufacture and construction as a capital goods industry

The second policy challenge concerns maintaining the momentum to strengthen local manufacturing and the installation of hydro. There is now a relatively strong hydro-mechanical industry in Nepal. In addition, Nepali companies are providing hydro services abroad such as in Pakistan, Afghanistan, Laos, India and Sri Lanka. One of the challenges for future policy is to balance the interests of this strong, flexible local hydro engineering industry with the challenges of outside contractors, sources of finance and the imports of generation, distribution equipment and electric appliances. Currently, as hydromechanical industries have produced turbine runners for projects smaller than $1 \mathrm{MW}$, the logical next level is production of such equipment for the small to medium hydro ( 1 to 100 MW) range. Secondly, Nepal needs to enter into production of electro-mechanical equipment (generators), perhaps, by collaborating with foreign industries.

\section{National Energy Policy}

It is beyond the scope of this paper to discuss the macro larger energy policy context in which hydropower is located, both nationally and globally. Now that Nepal is moving into a period where local electricity generation is projected to be in excess of demand under a range of tariff regimes, the case for such subsidies should be weaker ${ }^{99}$. It is probable that the recent blockade by India has resulted in a change in behaviour amongst energy consumers, whereby they have switched to electrical sources of energy, and are being more careful in its $u^{u s} e^{100}$. There is a policy opportunity, not only as a result of the blockade to change Nepal's overall energy policy but also to mitigate trade and balance of payment deficit, to displace not only fossil fuel inter alia for electrification of transportation and displacing of LPG from kitchens in near future and firewood from rural kitchen seventually.

\section{Managing the multiple and changing value and use of water and energy resources}

The fourth policy challenge concerns managing the inescapable complexity of water and energy resource use in Nepal and the changing institutions involved. This is not only at the local level, with respect to micro hydro, but also at a macro level. Many of the same issues come up, concerning water rights and electricity, sustainability and equitable distribution of cost and benefits in the short and long run. What is significant about Nepal at this juncture in time is that it has a wealth of experience in addressing these issues, and more importantly, a healthy instructional academic and political institutional context where this information and knowledge is available and enters onto policy debates. The challenge for Nepal will be how to address, manage and change the bureaucratic 'siloes' of existing government agencies, donor projects, NGOs, academic institutions and private/public investors. Moving on and letting 'water flow under the bridge' in the changing hydropower, water resources and economic context of today is difficult. In the politics of hydropower, whether it is in the political, academic or commercial arenas, water does not easily flow under the 
bridge! What is helping a 'moving on' is the growth and maturing of the hydro sector, especially in the private sector but also a renewed interest of academics and others who influence policy in the complexities of natural resource development ${ }^{101}$. Policy needs to be streamlined to ensure that projects related to water and energy supply, especially the large reservoir projects are built as multipurpose projects not only to meet increasing dry season and peak demand for electricity but also to meet ever increasing demand for water for purposes like drinking and irrigation. Trans-boundary issues also need to be addressed with reference to receiving recompense for negative externalities and sharing positive externalities.

\section{Technology 'Game Changers' in the electricity sector}

The fifth policy challenge concerns the huge contemporary range of engineering equipment for the generation and use of electricity. Some of this equipment changes the way electricity is thought about and used. A few years ago, it would have been unthinkable for a family in the mountains to speak to a migrant worker abroad. Now it is not only possible, but also normal, as a result of a mobile phone, recharged, for example, by a very small solar electricity unit on the top of the house. The change from incandescent bulbs to CFLs and now to LEDs greatly reduces usage and makes the saved electricity available for other uses. Similarly, the price of solar electricity has fallen significantly and is only now coming into a price range where it can be considered economically viable for irrigation purposes. More efficient induction cookers, which have spread recently due to the Indian blockade, increased the demand for electricity. The recent very rapid spread of the Chinese battery powered three-wheeler 'baby taxis' mainly on the Terai is an example of some of the major technical changes concerning electricity that are now taking place. It is estimated that there may be as many as 10,000 of these three wheelers on the Nepal Terai ${ }^{102}$. New (and old) equipment and knowledge for the careful use of electricity for water management in domestic and economic situations is getting more policy attention in Nepal. The challenge for policy analysts is to develop cost effective methods to keep up and learn from rapid changes already taking place on the ground. Further policy and other interventions should be expected for introduction of additional game changer technologies like cable car, ropeways, electric trolley buses, electric train in the valleys and plains, and electric and hybrid vehicles for urban.

\section{Managing Political Risk}

Finally, from a policy perspective there is the ever-present issue of how to manage risk ${ }^{103}$. The April 2015 earthquake in Nepal highlighted risks associated with different patterns of hydropower development. The damage to dams and other physical infrastructure were some of the more obvious physical outcomes of the earthquake. However, other risk considerations concern the room for manoeuvre for Nepali policy makers in a context of powerful neighbours and donors, in an ever-changing global, economic and technological environment. The deep economic effects of the Indian blockade from 2015 to 2016 emphasized the risks to Nepal of low investment in hydro capability before the 1990s - although the technical feasibility of hydropower generation and use had been well demonstrated in 1911. We suggest that if the current trends in the development of the hydro sector continue on to self-reliant energy security, Nepal will be much less vulnerable to political risks in the future.

Ratna Sansar Shrestha, FCA Independent researcher, Chairperson of Nepal Hydro \& Electric Ltd. and visiting faculty of School of Engineering, Kathmandu University, Nepal.

Corresponding E-mail: ratna.sansar@gmail.com

Stephen Biggs is Research Associate at Department of Development Studies, SOAS, University of London, WC1H oXG, UK.

\section{E-mail:biggs.s@gmail.com}

Scott Justice is Agricultural Mechanization Specialist at CIMMYT, Nepal.

\section{E-mail:s.justice@cgiar.org}

Amanda Manandhar Gurung is Executive Director at Chandra Gurung Conservation Foundation, Kathmandu, Nepal. She was appointed Executive Director and Member Secretary at CGCF's Annual General Meeting in late July, 2015. Amanda has been working tirelessly to implement CGCF's activities and plan future programs. With an undergraduate degree in Human Rights and Public Health from Bard College in New York and later a MA in Poverty and Development from the Institute of Development Studies at the University of Sussex, Brighton, UK, Amanda's experiences are as diverse as her background. She currently lives in Kathmandu, and is co-owner of the Base Camp: Outdoor Lifestyle.

\section{E-mail:amandamgurung@gmail.com}

\section{References}

AEPC (undated - c) Year-wise installation of Mini/ Micro Hydro (1985- July, 2016). Published online. Retrieved on 25 July 2017. http://www.aepc.gov.np $/$ ?option $=$ statistics $\&$ page $=$ substatistics $\&$ mid $=6 \& \mathrm{~s}$ ub_id=50\&id=1

AEPC (2013) NRREP Baseline Part B: Baseline of Renewable Energy Technology Installations in Nepal. Alternative Energy Promotion Centre(AEPC), National Rural and Rural Energy Programme (NRREP), Ministry of Science, Technology and Environment. GoN. Khumaltar, Nepal.

AEPC (undated - a) Improved Water Mill (IWM) Programme. Alternative Energy Promotion Center.http://www.aepc.gov.np/old/index. php?option $=$ com_content\&view $=$ article\&id $=$ 66\&Itemid=108. Retrieved 12 May 2016.

AEPC (undated - b) What is an Improved Water Mill (IWM)? Published online. Retrieved on 25 July 2017. http://www.aepc.gov.np/old/index. php?option=com_content\&view=category\&layout= blog\&id $=71 \&$ Itemid $=98$ 
AEPC, CRT and SNV (2014). Improved water mill development in Nepal: A status review. Kathmandu: Centre for Rural Technology (CRT) http:/ $\square /$ www. snv.org/public/cms/sites/default/files/explore/ download/iwm_status_report_2.pdf Retrieved 30 June 2016.

Allouche, J., Middleton C. and Gyawali, D (2015) Technical veil, hidden politics: Interrogating the power linkages behind the nexus. Water Alternatives 8(1): 610-626

Awale, S (2016) Storage projects: a must to reduce power shortage. The Himalayan Times. Perspectives. P. 1.

Bachmann, A and Nakarmi, AM (1983) New Himalayan Water Wheels. Kathmandu: Sahayogi Press.

Banerjee, SG, Singh, A and Samad, H (2011). Power and People: the Benefits of Renewable Energy in Nepal. A World Bank study. Washington, DC: World Bank. http://documents.worldbank.org/curated/ en/267921468053640845/Power-and-people-thebenefits-of-renewable-energy-in-Nepal

Bhushal, BR (2017) Nepalma Petroleum PadarthakoAapurtiByabasthapan (in Nepali: Management of Petroleum Product Supply in Nepal). Prabhat January 2017 (a publication of Nepal Oil Corporation).

Biggs, S and Justice, S (2015) Rural and Agricultural Mechanization: A History of the Spread of Small Engines in Selected Asian Countries. IFPRI Discussion Paper 01443. Washington: International Food Policy Research Institute

Biggs, S., Sharma, A., Uprety, R. and Justice, S (2017) Rural Change in the Kosi River Basin: A capital goods perspective. Paper for the Third International Conference on Bihar and Jharkhand: Shared History to Shared Vision, March 24-27, 2017. Asian Development Research Institute (ADRI), Patna, Bihar.

Bisht, KB (2010) Hydropower Nepal: resources, use and prospects. Kathmandu: Independent Power Producers' Association, Nepal.

Brown, J (2011) Water power and watermills: A historical guide. Marlborough, UK: The Crowood Press

Butler, C (2014) May you live in interesting times. HYDRO NEPAL. Issue no. 15. July. 21-22.

Chellaney, B (2011) Water: Asia's New Battleground. Washington, DC: Georgetown University Press

Colopy, C (2013) Dirty, Sacred Rivers: Confronting South Asia's Water Crisis. Vajra Books

Dhakhwa, K (2015) Nepal's Energy Demand: More than meets the eye. Nepal Economic Forum. Published December 16, 2015. http://www. nepaleconomicforum.org/blog/ detail.php? blog_ id=45 Retrieved 12 May, 2016.

Dixit, A and Gyawali, D (2010) Nepal's Constructive Dialogue on Dams and Development. Water Alternatives Vol. 3(2), pp. 106-123.

Engineering St. Gallen, Switzerland. (Austrian Development Co-operation). http://www. entwicklung.at/ uploads/media/897_o_projects in_namche_bazaar_and_rangjung_28_07.pdf Retrieved on 28 June 2016.

ENTEC AG (2001) Evaluation of Small Hydro Projects in Namche Bazaar (Nepal) and Rangjung (Bhutan). EZA Projekt: 1389. Prepared by: ENTEC AG, Consulting \&

Forster (undated) Chengdu Forster Technology Co., Ltd. Published online. Retrieved on 25 July 2017. https://forster-china.en.alibaba.com/

Gies, E (2012) Should Countries with no water be pushing for growth? Forbes/tech. http://www. forbes.com/sites/ericagies/2012/06/22/waterenergy-food-nexus-in-the-persian-gulf/ Retrieved on 26 August 2015.

GoN (1984) Nepal Electricity Authority Act, 2041 (1984). Retrieved online 30 July 2017. http://www. lawcommission.gov.np/en/documents/2015/o8/ nepal-electricity-authority-act-2041-1984.pdf

GoN (1992a) Electricity Act. Retrieved online 30 July, 2017. http://www.doed.gov.np/policy/electricityact-english.pdf

GoN (1992b) Water Resource Act. Retrieved online 30 July, 2017. http://www.moen.gov.np/pdf_files/ Water_Resources_Act_2049-english.pdf

GoN (1992c) Hydropower Development Policy. Retrieved online 30 July, 2017. http://www.nea.org. np/images/supportive_docs/4561Hydropower\%20 Development\%2oPolicy.pdf

GoN (2001) Hydropower Development Policy. Retrieved online 30 July, 2017. http://www. lawcommission.gov.np/en/documents/2015/o8/ hydropower-development-policy-2058-2001-2.pdf

GoN (2006) Rural Energy Policy, 2006. Ministry of Environment, Singha Durbar, Kathmandu.

GoN (2009) Report ofTwenty-Year Hydropower Development Task Force (in Nepali). Ministry of Energy.

GoN (2010). Investment Board Act, 2068 (2010). Retrieved online 30 July 2017.http://www. investnepal.gov.np/2ZmODFiZTkxZGZhNTQucGR mOjpJbnZlc3RtZW50IEJvYXJkIEFjdC5wZGY=

GoN (2017). Economic Survey Fiscal Year 2016/17. Ministry of Finance. Singh Durbar, Kathmandu. Retrieved online 30 July, 2017. http://mof.gov.np/ uploads/document/file/Economic\%20Survey\%20 English\%20-\%202016-17_20170713052055.pdf

Gyawali, D (2010) Hydro-Diplomacy and HydroInvestments Linkages, Problems and Prospects in Nepal. (In) AFCAN (2010) Pursuit of Economic Diplomacy: Prospects and Problems. Report of the Seminar/workshop. September 7-8, 2009. Kathmandu. Kathmandu: Association of Former Career Ambassadors of Nepal (AFCAN) pp. 63-78

Gyawali, D (2011). Drumbeats from a hawk. Review of Brahma Chellaney's book: Water: Asia's New Battleground. India: Harper Collins Publishers in BIBLIO, November-December. pp 8-9

Gyawali, D (2013). Reflecting on the chasm between water punditry and water politics. Water Alternatives Vol. 6(2) pp. 177-19.

Gyawali, D (2016) Collective Action on South Asia's 'Wicked Problems'. ORF Issue Brief. Issue 131. March 2016.

Gyawali, D and Dixit, A (1994) Prologue: Special Issue: Himalaya Ganga: Contending with Complexity. Water Nepal Vol. 4(1) pp. 1-6. 
Gyawali, D, Dixit, A and Upadhyaya, M. eds. (2004) Ropeways in Nepal: context, constraints and coevolution. Kathmandu: Nepal Water Conservation Foundation. PatanDhoka, Lalitpur. Nepal. (IABS: 99933-795-1-4).

IBN (2016). Energy Demand Projection 2030: A MAED Based Approach. Prepared jointly by NPC and IBN

International Energy Agency (undated). What is energy security? Published online. Retrieved on 25 July 2017. https://www.iea.org/topics/energysecurity/ subtopics/whatisenergysecurity/

Karki, A (2017) Micro and Small Hydro: Serial Leapfrogging to a Braver Nepal. Chapter 7 pp. 113-131 in Gyawali, D., Thompson, M. and Verweij, M (2017) Aid, Technology and Development: Lessons from Nepal. Routledge

Kienzle, J., Ashburner, JE and Sims, BG (eds) (2013) Mechanization for Rural Development: A review of patterns and progress from around the world. Plant Production and Protection Division, Food and Agriculture Organization of the United Nations (FAO), Rome.

Moore, D., Dore, J and Gyawali, D (2010) The World Commission on Dams + 10: Revisiting the large dam controversy. Water Alternatives 3(2): 3-13.

NEA (2014) Load Forecast Report. System Planning Department, NEA, July 2014.

NEA (2016) A Year in Review - Fiscal Year 2015/16. Durbar Marg, Kathmandu, Nepal. http://www.nea. org.np/images/supportive_docs/NEA\%2odesign. pdf Retrieved on 25 July 2017.

Nepal Energy Forum (undated-a) Govt. aims to sell 5700MW to India. Published online. Retrieved on 30 July, 2017. http://www.nepalenergyforum.com/ govt-aims-to-sell-570omw-to-india/

Nepal Energy Forum (undated-b) West Seti Hydropower Project by 2021. Published online. Retrieved on 25 July 2017. http://www.nepalenergyforum.com/ west-seti-hydropower-project-by-2021/

Nepal Micro Hydropower Development Association (undated) $\mathrm{MH}$ Introduction. http://www. microhydro.org.np/ Retrieved on 2 September 2015.

Office of the Investment Board (undated) About. Published online. Retrieved on 26 July 2017. http:// ibn.gov.np/about

Pandey, B (2016) Track II - Nepal's Pluralistic Hydropower Development Post-Arun. Chautari Book Series - 87. Kathmandu: Martin Chautari (Published version of a seminar on February 22, 2015)

Pandey, K (2007) Review of Dam Development: The Dynamics of Social Inequality in a Hydropower Project in Nepal by Kavita Rai. Studies in Nepali History and Society, Volume 12 No. 2 December. 2007 (Pus 2064 v.s.). pp. 414-419.

Pearce, F (2012) Beyond big dams: turning to grass roots solutions on water. Yale Environment. No. 36o. http://e36o.yale.edu/feature/beyond_big_ dams_turning_to_grass_roots_solutions_on_ water/2571/ Retrieved 26 August 2015.

Power Paradox (2014, November 10). The Rising Nepal. http://trn.gorkhapatraonline.com/index.php/ editorial/1773-power-paradox.htmlRetrieved 26
August 2015 .

Pradhan, GL (2011) Power can be our most valuable export. Nepali Times. No. 553. 13 - 19 May 2011.

Pun, SB (2014) 6,480 MW Pancheshwar Multipurpose Project: Six vital issues on Pancheshwar to be addressed before cashing Modi's one Billion US dollars. HYDRO NEPAL. Issue no. 15. July. Pp. 7-15.

Pun, SB (2015) Utilizing India's one billion dollar line of credit: Budhi Gandaki, Mahakali III and Bridge of Mahakali - projects born and bred at Singha Durbar? HYDRO NEPAL. Issue no. 16. January Pp. 2-7.

Rai, OA (2017). Cloud with a dark lining. Nepali Times (\#848), 3-9 March 2017.

Regmi, A (2004). Democratising micro-hydel: Structures, systems and agents in adaptive technology in the hills of Nepal. Hyderabad, India: Orient Longman

Republica (2016a) Nepal China to have Joint Cooperation Mechanism Similar to India. Published March 2016. http://admin.myrepublica.com/ economy/story/39278/nepal-china-to-have-jointcooperation-mechanism-similar-to-india.html Retrieved on 28 June 2016

Republica (2016b) Extending Rail Link to Nepal No Big Deal Chinese Experts. Published June 2016. http://admin.myrepublica.com/feature-article/ story/43588/extending-rail-link-to-nepal-no-bigdeal-chinese-experts.html Retrieved on 21 June 2016

Sadoff, C., Rao, H and World Bank Team. (2011) The Ganges Strategic Basin Assessment. World Water Week, 21-27 August, 2011. Stockholm. http:// www.worldwaterweek.org/ documents/WWW_ PDF/2011/Sunday/K23/Promoting-Cooperationin-the-Ganges-Basin-through-Dialog/The-GangesStrategic-Basin-Assessment.pdf

Shakya, S (2009). Unleashing Nepal: Past. Present and future of the economy. New Delhi: Penguin.

Shrestha, HM hyonnichVisokogornikhRainonovPrimenitelno ko UsloviyamNepala(CascadeofPotentialHydroelectric Resources of Poorly Studied High Altitude Regions with Application to Conditions of Nepal), PhD thesis, MoskovskyEnergeticheskyInstitut (Moscow Energy Institute), USSR.

Shrestha, RS (2000). Managing Risks in Private Sector Hydro Development in Nepal. HRW Journal, November 2000.

Shrestha, RS (2001) Economic Viability of Khumbu BijuliCompany in Rachbauer D, Energy from the Top of the World. Eco Himal, 2001.

Shrestha, RS (2006) Nepal is not Bhutan. Nepali Times, September 8, 2006

Shrestha, RS (2007a).Investment in Hydropower Sector in Nepal: Opportunities and Risks. The Nepal Chartered Accountant (Journal of the Institute of Chartered Accountants of Nepal), September/ December 2007

Shrestha, RS (2008a).Hydropower Development Irrelevant Debate of Small vs. Big.Water Resource Management of Nepal: A Strong Means for Sustainable National Development.Institute of 
Foreign Affairs, January 2008

Shrestha, RS (2008b).Modifying Melamchi - Single Purpose vs. Multipurpose. New Business Age,March 2008

Shrestha, RS (2008c).Pie in the sky (Mythical Hydro Dollars). The Kathmandu Post, January 9, 2008

Shrestha, RS (2009a). A Case Study of Khumbu Bijuli Company. Published online. Retrieved 25 July 2017. http://www.ratnasansar.com/search?q=khumbu

Shrestha, RS (2009b).Arun III Project: Nepal's Electricity Crisis and its Role in Current Load Shedding and the Potential Role 10 Years Hence. Hydro Nepal, January 2009

Shrestha, RS (2009c). New Nepal Plunge in Darkness. BOSS January 2009.

Shrestha, RS (2010a).Electricity Crisis (Load shedding) in Nepal - Its Manifestations and Ramifications. Hydro Nepal: Journal of Water, Energy and Environment, January 2010

Shrestha, RS (2010b)."Power” to India. Nepali Times, August 27, 2010.

Shrestha, RS (2010c). Upper Karnali Uproar! Spotlight, March 5, 2010

Shrestha, RS (2011a), Dreams of Jaded System and Load shedding in Nepal. (Transcript of interview). Greatway. February 2011.

Shrestha, RS (2011b). Hydrocratic dreams: Using hydro-dollars to mitigate our trade deficit is a mirage. Nepali Times, May 13, 2011.

Shrestha, RS (2011c). Paschim SetiAayojana - Sahraniya Kam (in Nepali: West Seti Project - Appreciable Work). Gorkhapatra, August 6, 2011.

Shrestha, RS (2012a). Bearing Burnt of Load Shedding. Greatway, February 2012.

Shrestha, RS (2012b). Load Shedding Mitigation Measures Lacks Efficacy. Spotlight, November 2012.

Shrestha, RS (2014a) Export of Electricity is Mutually Exclusive with Domestic Consumption. Peoples Review. October 30, 2014.

Shrestha, RS (2014b). Mahakali Water to Quench Delhi's Thirst. Spotlight, December 26, 2014.

Shrestha, RS (2014c). Implementing Pancheshwar Project in Nepal's Interest. Spotlight. July 25, 2014.

Shrestha, RS (2015a). "Export" of National Interest in Upper Karnali. Peoples Review. January 22, 2015.

Shrestha, RS (2015c). Hydropower and Hydrocratic Intellectuality. Peoples Review March 4, 2015.

Shrestha, RS (2016a).Hydropower Development: Before and After 1992. Hydro Nepal Journal of Water, Energy and Environment. January 2016.

Shrestha, RS (2016b). Parliamentary Ratification of PDAs. Peoples Review. December 2016.

Shrestha, RS (2017a). Hydropower Policy - A Critique. Hydro Nepal Journal of Water, Energy and Environment. January 2017.

Shrestha, RS (2017b). Jal Ra BidyutUrjaSurakshyaBismriti Ma Pareko Jal BidyutNiti(in Nepali: Hydropower Policy that ignores water and electric energy security). Nagarik, April 9, 2017.

Shrestha, RS (2017b). Large hydro: failures in financial engineering. In D. Gyawali,M. Thompson and $\mathrm{M}$ Verweij (eds) Aid, Technology and Development.
Earthscan from Routlege, London. January 2017.

Sovacool, Benjamin K., Saroj Dhakal, Olivia Gippner, Malavika Jain Bambawale, Halting hydro: A review of the socio-technical barriers to hydroelectric power plants in Nepal, Energy, Volume 36, Issue 5, May 2011, Pages 3468-3476, ISSN 0360-5442, http://dx.doi.org/10.1016/j.energy.2011.03.051. (http://www.sciencedirect.com/science/article/ pii/So360544211002192)

Subedi, B (2017) 160 MW Power deal signed. The Kathmandu Post. May 28, 2017. http:// kathmandupost.ekantipur.com/news/2017-0528/160-mw-power-deal-signed-nea.html

Sugden, F., Shrestha, L., Bharati, L., Gurung, P., Maharjan, L., Janmaat, J., Price, JI., Sherpa, TYC., Bhattarai, U., Koirala S and Timilsina, B (2014) Climate change, out-migration and agrarian stress: The potential for upscaling small-scale water storage in Nepal. IWMI Research Report 159. Colombo, Sri Lanka: International Water Management Institute. http://programme.worldwaterweek.org/sites/ default/files/rr159.pdf

Svalheim, P (2015) Power for Nepal: Odd Hoftun and the History of Hydropower Development, Kathmandu, Nepal: Martin Chautari.

Thake, J (2000). The micro-hydro pelton turbine manual: design, manufacture and installation for small-scale hydropower. ITDG Publishing. London, UK.

Upadhyaya, SK (2002) Hydropower Development in Nepal: Issues of Equity and Environmental Justice. Equitable Hydro Working Paper 1. Winrock International, Kathmandu, Nepal

WECS (2017) Electricity Demand Forecast Report (2014-2040)

World Bank (2014)Diesel Power Generation: Inventories and Black Carbon Emissions in Kathmandu Valley, Nepal. Washington DC. http://www.cen.org.np/ uploaded/1948_[final]\%20Report_DG\%20Set\%20 Study_Nepal.pdf Retrieved on 25 July 2017

World Databank (2016) World Development Indicators. The World Bank Group. http://databank.worldbank. org $/$ data $/$ reports.aspx ? source $=2 \&$ type $=$ metadata $\&$ series=EG.USE.ELEC.KH.PC\# Retrieved on 12 May 2016.

\section{Footnotes}

1. Similar sentiments to this Newspaper article are expressed by Sovacool, et al., 2011 in the Journal Energy.

2. Banerjee, SG, Singh, A and Samad, H (2011). Power and People: The Benefits of Renewable Energy in Nepal. A World Bank study. Washington, DC: World Bank.

3. It would not be possible to displace aviation turbine fuel with existing technology.

4. Should Countries with no water be pushing for growth? Forbes/tech. http://www.forbes.com/ sites/ericagies/2012/06/22/water-energy-foodnexus-in-the-persian-gulf/ Retrieved on 26 August 2015 .

5. Allouche, J., Middleton C. and Gyawali, D (2015) Technical veil, hidden politics: Interrogating the 
power linkages behind the nexus. Water Alternatives 8(1): 610-626

6. Shrestha, RS Modifying Melamchi - Single Purpose vs. Multipurpose. New Business Age, March 2008

7. There is no holding and releasing policy of water in the existing body of policy and law. Both the Hydropower Development Policy of 1992 and 2001 are silent in this respect, and same is the case with Electricity Act, 1992 and Water Resource Act 1992, due to lack of which Nepal would be holding and releasing water based only on the requirement for electricity generation, with no regard to consumptive use in downstream areas of Nepal. This also results in India receiving lean season augmented flow free of cost without having to recompense for negative externalities that Nepal suffers and share positive externalities that India would enjoy. Budhi Gandaki project, $1,200 M W$, is a case in point(Shrestha, RS. Large hydro: failures in financial engineering. In D. Gyawali, M. Thompson and M Verweij (eds) Aid, Technology and Development. Earthscan from Routlege, London. January 2017.Since this project is not developed as a multipurpose project, the project too will have no water holding and releasing policy except on the basis of demand for electricity it generates, and lean season augmented flow of this project will be provided to India for free.

8.For some recent discussions of this broader Himalayan picture see Pearce, F (Beyond big dams: turning to grass roots solutions on water. Yale Environment. No. 360),Sadoff et al (Sadoff, C., Rao, H and World Bank Team. The Ganges Strategic Basin Assessment. World Water Week, 21-27 August 2011. Stockholm), Chellaney B. (Water: Asia's New Battleground. Washington, DC: Georgetown University Press, 2011) Dixit and Gyawali (Nepal's Constructive Dialogue on Dams and Development. Water Alternatives2010), Gyawali (Hydro-Diplomacy and Hydro-Investments Linkages, Problems and Prospects in Nepal. (In) AFCAN 2010, Drumbeats from a hawk. Review of Brahma Chellaney's book: Water: Asia's New Battleground. India: Harper Collins Publishers, 2011 and 2013), Colopy C. (Dirty, Sacred Rivers: Confronting South Asia's Water Crisis. Vajra Books andReflecting on the chasm between water punditry and water politics. Water Alternatives,2013) and the earlier Gyawali and Dixit (Prologue: Special Issue: Himalaya Ganga: Contending with Complexity. Water Nepal 1994). Recently Gyawali (Collective Action on South Asia's 'Wicked Problems'. ORF Issue Brief 2016) suggests that the South Asian Association for Regional Cooperation (SAARC) formed in 1985 might mobilise more to address some of the deeply political issues involved.

9. When the import of petroleum products such as liquefied petroleum gas, diesel and petrol dropped dramatically, the response was a much higher dependence on electricity for cooking and transportation (electric vehicles).

10. However, the private sector has seized theopportunity by pressing electric three wheelers (pioneered as Safa Tempo) into service in Kathmandu and Terai, about
10,000 in total. Some clean energy enthusiasts are riding electric cars: initially Reva and followed by E2O of Mahindra, Soul of Kia and BYD from China. 11. The estimated demand for 15 yearsis as follows:

Unit 2016/17 2031/32

\begin{tabular}{llll} 
Petrol kL & \multicolumn{3}{l}{$324,8001,587,334$} \\
Diesel kL & 1,002,800 & $3,351,084$ \\
Kerosene & kL & 20,330 & 52,422
\end{tabular}

ATP kL 156,510 674,627

LPG MT 293,8001,626,110

(in Bhushal, BRNepalma Petroleum PadarthakoAapurtiByabasthapan (in Nepali: Management of Petroleum Product Supply in Nepal). Prabhat January 2017 (a publication of Nepal Oil Corporation)

12. As far as we know there are no historical studies of water mills going back to the early 1900 .

13. Brown, J (2011) Water power and watermills: A historical guide. Marlborough, UK: The Crowood Press

14.Bachmann, A and Nakarmi, AM (1983) New Himalayan Water Wheels. Kathmandu: Sahayogi Press.

15.Sadly Mr. Narkarmipassed away earlier this year. 16.AEPC (Undated).Improved Water Mill (IWM) Programme. And AEPC, CRT and SNV (2014). Improved water mill development in Nepal: A status review. Kathmandu: Centre for Rural Technology

17. Rural Energy Policy, 2006. Ministry of Environment 18. Micro and Small Hydro: Serial Leap-frogging to a Braver Nepal. Chapter 7 pp. 113-131 in Aid, Technology and Development: Lessons from Nepal. Rouledge.

19.Kadasar Potentsialnikh Gedro energetic hesih Resursov Malizuchyonnich Visokogornikh Rainonov Primenitelno ko UsloviyamNepala(Cascade of Potential Hydroelectric Resources of Poorly Studied High Altitude Regions with Application to Conditions of Nepal), PhD thesis, MoskovskyEnergeticheskyInstitut (Moscow Energy Institute), USSR.

20.This estimate was made in 1966 , at a time when very little river water discharge data was generated by very few measuring stations and the researcher, for his $\mathrm{PhD}$ thesis, used average runoff discharge that includes the floodwater as well. As another credible estimate is yet to be produced even after 50 years, it is these numbers that are extensively used by the Government, academia, hydro industry, media, etc.Nepal Oil Corporation (NOC) has claimed in 2012 that the country has been generating around $531 \mathrm{MW}$ of electricity through the use of diesel run by industries, hotels, factories, and urban households (World Bank (2014) Diesel Power Generation: Inventories and Black Carbon Emissions in Kathmandu Valley, Nepal. Washington DC.). This is largely to meet the shortfall and unreliability of supplies from the grid system. From a national economic perspective, this is a very expensive source of energy, as all petroleum products are imported from India, and sold at subsidized prices.

21. NEA:A Year in Review - Fiscal Year 2015/16. 22.Rampant load shedding continues outside the 
capital even after declaration of end of loadshedding but no loadsheddingschedule is published, a break from past practice.

23. Nepal Energy Forum (undated-a) Govt. aims to sell $5700 \mathrm{MW}$ to India. (undated)

24. Rai, OA.Cloud with a dark lining. Nepali Times (\#848), 3-9 March 2017.

25. Subedi (2017)

26. Shrestha, RS. Hydropower and Hydrocratic Intellectuality. Peoples Review March 4, 2015.

27. Shrestha, RS...Jal Ra BidyutUrjaSurakshyaBismriti Ma Pareko Jal BidyutNiti(in Nepali: Hydropower Policy that ignores water and electric energy security). Nagarik, April 9, 2017.

28.To displace firewood from rural kitchen will be overambitious at the moment

29.Biggs, S., Sharma, A., Uprety, R. and Justice, S (2017) Rural Change in the Kosi River Basin: A capital goods perspective. Paper for the Third International Conference on Bihar and Jharkhand: Shared History to Shared Vision, March 24-27, 2017. Asian Development Research Institute (ADRI), Patna, Bihar

30.First author has extensive experience in hydropower sector including as Deputy General Manager of Himal Power Ltd. (developer/owner of the 6oMW Khimti Hydropower Project), member of board of directors of NEA and Butwal Power Company (BPC), Senior Advisor of clean energy group of Winrock International, Senior Energy Economist of Small Hydropower Promotion Project under the then GTZ and currently Chairperson of Board of Directors of Nepal Hydro and Electric (Ltd) and visiting faculty of School of Engineering under Kathmandu University.

31.We have been selective in the references cited here.

32. Such as for moving and storing water for irrigation purposes, powering maize hullers, and other local processing and manufacturing activities. In recent years there has been renewed interest in patterns of rural and agriculturalmechanization and the spread of small and large engines for providing power in rural areas (Kienzle, J., Ashburner, JE and Sims, BG (eds) (2013) Mechanization for Rural Development: A review of patterns and progress from around the world. Plant Production and Protection Division, Food and Agriculture Organization of the United Nations (FAO), Rome). However, hydropower and its distribution systems - of any scale- while clearly an important element in those policy debates, is often not included. One of the goals of this research was to address this issue.

33. For a critical review of hydropower policy refer to Shrestha, RS.Hydropower Policy - A Critique. Hydro Nepal Journal of Water, Energy and Environment. January 2017.

34.In Nepal, it usually means fitting generators on traditional water mills.

35.Bisht, KB (2010) Hydropower Nepal: resources, use and prospects. Kathmandu: Independent Power Producers' Association, Nepal.

36.Task Force constituted by GoN to prepare Generation Plan to generate 25,00oMW in 20 years

recommended following capacity classification (GoN 2009):

Task Force Recommendation

Micro:

Mini:

Small:

Medium:

Large:

Mega:

$$
\begin{aligned}
& <100 \mathrm{~kW} \\
& 100 \mathrm{~kW}-1 \mathrm{MW} \\
& 1-25 \mathrm{MW} \\
& 25-100 \mathrm{MW} \\
& 100-1000 \mathrm{MW} \\
& >1000 \mathrm{MW}
\end{aligned}
$$

37.For further discussions on Nepal see Bisht (2010), Dixit and Gyawali (2010), and Gyawali (2010, 2013) and Pradhan (2011). Upadhyaya (2002) in the early 2000 s wrote a series of 6 working papers for Winrock International on the equity and justice dimensions of hydropower development in Nepal.Sujeev Shakya's book Unleashing Nepal (2009) also has a section entitled "Making Hydropower Happen". Opportunities for investment in hydropower sector, or lack of it is specifically discussed in Shrestha (2007a)

38.India's recent national grid failure where over 400 million people lost electricity at one time will likely accelerate this interest. It should be said that while there is considerable loadshedding also in India, this was the world's largest power failure.

39.Refer to Shrestha, RS. "Export" of National Interest in Upper Karnali. Peoples Review. January 22, 2015

40.For a map of the Ganges basin, that highlights the way Nepal's water and hydropower resources are of interest to India, see Sadoff, C., Rao, H and World Bank Team. The Ganges Strategic Basin Assessment. World Water Week, 21-27 August 2011. Stockholm), For a critical review of one of the Indian strategic policy positions see Gyawali, D.Drumbeats from a hawk. Review of Brahma Chellaney's book: Water: Asia's New Battleground. India: Harper Collins Publishers. 2011.

41. Well documented by the World Commission on Dams in 2000, and the issues revisited in 2010 by Moore, D., Dore, J and Gyawali, D.The World Commission on Dams + 10: Revisiting the large dam controversy. Water Alternatives 2010) with a specific analysis of Nepal's policies and practices since 2000.

42.Shrestha, RS. Large hydro: failures in financial engineering. In D. Gyawali,M. Thompson and M Verweij (eds) Aid, Technology and Development. Earthscan from Routlege, London. January 2017.

43.For a recent example of this see Gyawali,,D. Reflecting on the chasm between water punditry and water politics. Water Alternatives, 2013

44.For example, GoN and CWE Investment Corporation (CWEI), a subsidiary of China Three Gorges Corporation (CTGC), signed a memorandum of understanding in August 2012 to develop the $750 M W$ West Seti project in the far West of Nepal for local use rather than export. It is the only reservoir project ready for construction and is planned for completion in 2021 (Nepal Energy Forum). Its previous incarnation was proposed to be export oriented by West Seti Hydro Limited, subsidiary of Snowy Mountain Engineering Corporation, but 
after the Asian Development Bank (ADB) declined to finance it in view of stiff opposition to it in Nepal, it impelled the government to cancel the license in July 2011(Shrestha, RS. Paschim SetiAayojana - Sahraniya Kam (in Nepali: West Seti Project Appreciable Work). Gorkhapatra, August 6, 2011). Pandey gives details of local and foreign investors in current and planned industrial hydro (in Track II - Nepal's Pluralistic Hydropower Development Post-Arun. Chautari Book Series - 87. Kathmandu: Martin Chautari)

45.For a list and discussion of existing and potential storage project see AwaleS (Storage projects: a must to reduce power shortage. The Himalayan Times. Perspectives). There is $802 \mathrm{MW}$ capacity in the national grid in the wet season, this falls to $340 \mathrm{MW}$ in the dry season giving rise to load shedding in this season (NEA, Annual Report 2016). The need for storage dams comes also from the need to address fluctuating electricity demand. Currently Kulekhani I (6oMW) and its cascade Kulekhani II (32MW) are the only reservoir/storage projects in Nepal. Potential other hydro storage dams are West Seti (750MW), Budhi Gandaki (1,200MW), Tanahu (140MW), Nalsing Gad (40oMW) and others. The balancing of supply and demand of electricity can be met also by electricity trade agreements, and these are discussed at the end of the paper.

46.According toThe Kathmandu Post of February 26, 2018.

47.Subedi, B. 160 MW Power deal signed. The Kathmandu Post. May 28, 2017

48.For details see Bisht, KB. Hydropower Nepal: resources, use and prospects. Kathmandu: Independent Power Producers' Association, Nepal.2010.

49.For a recent history of Odd Hoftun and early hydro development in Nepal see Svalheim (2015). This detailed history of Odd Hoftun and of the NGO, United Mission to Nepal (UMN) describes the development of improved water mills, the early micro hydro $(50 \mathrm{~kW})$ on the Tinau and subsequent increases to the $1 \mathrm{MW}$, the Andhi Khola Hydro (5.1MW), which was upgraded to $9.4 \mathrm{MW}$ and commissioned in April 2015, the Jhimruk (12MW) and the Khimti Hydro of 60 MW.

50.For a brief history of the origins in 1972 of the Development and Consulting Services (DCS) and subsequent work see Thake, J. The micro-hydro pelton turbine manual: design, manufacture and installation for small-scale hydropower. ITDG Publishing. London, UK.(200o). Details are also given on the thinking behind using improved water mill turbines for supply of electricity to surrounding villages and bazaar lighting. Electronic load controllers (ELC) were just becoming available in the early 1980 s and made this possible. In the 1980s, DCS started to introduce and develop Pelton turbines with ranges between $2 \mathrm{~kW}$ and $200 \mathrm{~kW}$ as they were ideal for the high head and low flow conditions of many situations in the mid hills and mountains of Nepal.

51.Regmi, A. Democratising micro-hydel: Structures, systems and agents in adaptive technology in the hills of Nepal. Hyderabad, India: Orient Longman. 2004.

52.The Patan Industrial Estate serves the Kathmandu valley.

53.For example, Cream Hydel Private Ltd was established in 2009 to work on hydro above $1 \mathrm{MW}$ - in the first phase to manufacture and repair hydromechanical components ranging from 1 to $10 \mathrm{MW}$ and in the second phase to expand above 10MW. The company would also continue to work in the micro hydro sector.

54.For more details see Shrestha, RS A Case Study of Khumbu Bijuli Company. Published online.2009

55.For details see ENTEC AG (2001) Evaluation of Small Hydro Projects in Namche Bazaar (Nepal) and Rangjung (Bhutan). EZA Projekt: 1389. Prepared by: ENTEC AG, Consulting \& Engineering St. Gallen, Switzerland. (Austrian Development Co-operation).

56.Shrestha, RS.Hydropower Development: Before and After 1992. Hydro Nepal Journal of Water, Energy and Environment. January 2016.

57.Tinau was the first power plant built by BPC using similar financing modality with $50 \mathrm{~kW}$ as installed capacity initially, which was eventually upgraded to $1,024 \mathrm{~kW}$ in a number of phases. It was handed over to GoN on July 18,1980 and GoN in turn handed it over to NEA and it is still operational (Svalheim, P. Power for Nepal: Odd Hoftun and the History of Hydropower Development, Kathmandu, Nepal: Martin Chautari. 2015).

58.In 2001 a new Hydropower Development Policy 2001) was promulgated to supplant existing policy. But the Electricity Act is yet to be amended to bring it in line with new policy, resulting in incongruent inconsistencies between new policy and existing Acts. The Electricity Bill was tabled in 2009, to displace existing one, but as it attracted almost 150 amendments, no effort was made to get it passed by the Parliament.

59.As has been explained above Tinau, Andhi Khola and Jhimruk plants built with Norwegian assistance are exceptions.

6o.Installed capacity of Arun 3 was 402MW, but it was downsized to 201MW and called "Baby Arun" and it was this scheme that World Bank cancelled in August 1995.

61.Pandey, B (2016) Track II - Nepal's Pluralistic Hydropower Development Post-Arun. Chautari Book Series - 87. Kathmandu: Martin Chautari (Published version of a seminar on February 22, 2015)

62.For a detailed review of cancellation of Arun 3 in 1995 due to withdrawal of support by World Bank and its ramifications refer to Shrestha RS.Arun III Project: Nepal's Electricity Crisis and its Role in Current Load Shedding and the Potential Role 10 Years Hence. Hydro Nepal, January 2009

63.The AEPC has many programs besides microhydro and water mills, such as solar energy, biogas, and wood stoves. We are concerned here with the hydro side of its programs.

64.This includes pico, micro, mini hydro, i.e., everything 
up to $1 \mathrm{MW}$ (AEPC undated $-\mathrm{c}$ ). The Nepal Micro Hydropower Development Association website (September 2015) gives the total capacity of micro hydropower plants as 28MW with 2,900 microhydro units. The website also says that although in the past microhydro used to generally refer to units of up to $100 \mathrm{~kW}$, in the future units of up to $1 \mathrm{MW}$ will also be called microhydropower.

65. Shrestha, RS Hydropower Development: Before and After 1992. Hydro Nepal Journal of Water, Energy and Environment. January 2016.

66.NEA. Annual Report for 2015/16

67.Including Jhimruk, 12MW, built by BPC with Norwegian financial assistance, even before the sector was liberalized under Hydropower Development Policy announced in 1992.

68.NEA. Annual Report for 2015/16

69. This section is based on Pandey (2016).

70.Refer to Shrestha, RS. Mahakali Water to Quench Delhi's Thirst. Spotlight, December 26, 2014 and Shrestha, RS. Implementing Pancheshwar Project in Nepal's Interest. Spotlight. July 25, 2014.

71. Odd Hoftun was also instrumental in setting up Himal Hydro and General Construction Ltd. (commonly known as Himal Hydro) in February 1978 to work in hydropower, tunneling, transmission line, ropeways, water \& wastewater and general construction (Svalheim, P (2015) Power for Nepal: Odd Hoftun and the History of Hydropower Development, Kathmandu, Nepal: Martin Chautari).

72.This is illustrated by a stand in the March 2015 Trade Fair in Kathmandu where Chengdu Forster were exhibiting (with videos) of a whole range of axil flow, turgo, Francis and other turbines suitable for a wide range of Nepal micro hydro conditions. Local importers in Kathmandu are now selling this Chinese equipment. Several off the shelf pico range 400-800 watt models are currently available in Teku Bazaar starting around 350.00 USD.

73.See Shrestha RS.Hydropower Development Irrelevant Debate of Small vs. Big.Water Resource Management of Nepal: A Strong Means for Sustainable National Development.Institute of Foreign Affairs, January 2008 for more details on the concept of economic linkages.

74.Dhakhwa, K Nepal's Energy Demand: More than meets the eye. Nepal Economic Forum. Published December 16, 2015

75.NEA. Load Forecast Report. System Planning Department, NEA, July 2014.

76.WECS (2017) Electricity Demand Forecast Report (2014-2040)

77.IBN (2016). Energy Demand Projection 2030: A MAED Based Approach. Prepared jointly by NPC and IBN

78.World DataBank - World Development Indicators. Incidentally, the increasing trend is not mainly on account of increase in intensity of electricity consumption; rather due to increasing access to electricity.

79.NEA. Annual Report for 2015/16

80.Shrestha, RS (2010a).Electricity Crisis (Load shedding) in Nepal - Its Manifestations and
Ramifications. Hydro Nepal: Journal of Water, Energy and Environment, January 2010

81.In urban areas the separation of domestic and productive use of electricity is a very grey area, and differential tariffs for different purposes is very difficult to design and effectively implement. For example, when small electric saws and drills are used for making furniture, they might pay the lower domestic tariff as is charged for domestic microwaves, electric heaters, etc. In rural areas, some of the problems of community level micro hydro units are due to excessive loads as higher wattage equipment is plugged in. Many micro hydro systems have been established to supply electricity for household lights and appliances, with little attention to using electricity for productive uses. Recently there has been a change in policy and the AEPC has switched to the National Rural and Renewable Energy Programme where there is more concern with the economic use of electricity.

82.Some of these are cooperatives, others NGOs

83.Nepal Oil Corporation (NOC) has claimed in 2012 that the country has been generating around $531 \mathrm{MW}$ of electricity through the use of diesel run by industries, hotels, factories, urban households, etc. (World Bank. Diesel Power Generation: Inventories and Black Carbon Emissions in Kathmandu Valley, Nepal. Washington DC. 2014).The Indian de facto fuel embargo of 2015/16 highlighted Nepal's dependence on fossil fuels from India.

84.Nepal had a Department of Electricity under the then Ministry of Water Resources till the Nepal Electricity Authority was created in August 1985underNepal Electricity Authority Act, 2041 (1984) through the merger of this department with the Nepal Electricity Corporation, Eastern Electricity Corporation and related development boards. The logic was that, with the establishment of NEA, there is no need for a separate department. But after establishing EDC, DoED was brought into existence through the back door.

85.See Butler C.May you live in interesting times. HYDRO NEPAL. Issue no. 15. July. 21-22., 2014 for a discussion of some of the institutional battles that have taken place since the start of the IBN, and dynamics of current changes.

86.Nepal's largest FDI deal worth $\$ 1.4$ billion and its developer is GMR Upper Karnali Hydropower Limited (an Indian private sector entity).

87.Shrestha, RS (2016b). Parliamentary Ratification of PDAs. Peoples Review. December 2016.

88.Its developer is SJVN Arun-3 Power Development Company Ltd. a subsidiary of Sutlej Jal Vidyut Nigam, latter owned jointly by central government of India and Himachal Pradesh government and the project is expected to come on line in 2021.

89.Interestingly, a PTA had already been signed with India in 1997 which was never brought into force as it failed to secure parliamentary ratification. It was never formally tabled for ratification in the parliament.Under Nepal's constitution of both 1990 and 2015, any treaty/agreement signed by the Nepali government related to water resources needs 
parliamentary ratification and, this treaty could be deemed unconstitutional if ever subjected to judicial examination.

90.For example see Gyawali, D. Hydro-Diplomacy and Hydro-Investments Linkages, Problems and Prospects in Nepal. (In) AFCAN (2010) Pursuit of Economic Diplomacy: Prospects and Problems. Report of the Seminar/workshop. September 7-8, 2009. Kathmandu. Kathmandu: Association of Former Career Ambassadors of Nepal (AFCAN)),Pun, SB (2014) 6,480 MW Pancheshwar Multipurpose Project: Six vital issues on Pancheshwar to be addressed before cashing Modi's one Billion US dollars. HYDRO NEPAL

91.See Pun $(2014,2015)$. The three projects are Budhi Gandaki reservoir storage hydropower project (1,200 MW with resettlement implications), the Mahakali III and the Kosi pumped canal project, and the bridge over the Mahakali river. The author, S.B. Pun is a former Managing Director of the Nepal Electricity Authority and then Officer on special duty at the then Ministry of Water Resources. (Pun, SB .6,480 MW Pancheshwar Multipurpose Project: Six vital issues on Pancheshwar to be addressed before cashing Modi's one Billion US dollars. HYDRO NEPAL. Issue no. 15. July. 2014).

92.Shrestha, RS (2010b)."Power" to India. Nepali Times, August 27, 2010.

93.See Pandey, K .Review of Dam Development: The Dynamics of Social Inequality in a Hydropower Project in Nepal by Kavita Rai. Studies in Nepali History and Society, Volume 12 No. 2 December. 2007

94.For example, for discussions of the pros and cons of past decisions see Butler,C.May you live in interesting times. HYDRO NEPAL. Issue no. 15. July. 21-22, 2014),Pun, SB.Utilizing India's one billion dollar line of credit: Budhi Gandaki, Mahakali III and Bridge of Mahakali - projects born and bred at Singha Durbar? HYDRO NEPAL. Issue no. 16. January 2015.

95.In our considered opinion, GoN should not undertake this responsibility; rather the developer should be made responsible for this activity and GoN should regulate and monitor to ensure that displacees are resettled in accordance with internationally accepted norms.

96.A visit to Chengdu Forster's technology on the Alibaba website shows an amazing array of small and large hydro equipment for sale including the small Kaplan units that are currently for sale in Kathmandu hardware shops along-side irrigation pump sets, mini tillers, etc.

97.See the RepublicaNepal China to have Joint Cooperation Mechanism Similar to India. Published March 2016

98.In a recent Republica"Extending Rail Link to Nepal No Big Deal Chinese Experts" published in June 2016article, Chinese experts claim the rail link is technologically "no big deal". If building a trans-Himalaya railway is "no big deal" then one could imagine that trans-Himalaya high-tension transmission lines might also be a "no big deal".

99.In no country is the pricing of energy, whether fossil fuels or renewables, outside of government policy, and hence these prices are always a policy decisionhence a political decision. It is beyond the scope of this paper to look at the contemporary role of the public and private sectors in Nepal's energy sectors. 100.The careful and efficient use of the grid has been helped by the bulk selling of electricity to community electrification entities since the early 2000s. This tariff system for the National grid is continuing to spread.

101. Recent interest is reflected in the work of Sugden et al. (Climate change, out-migration and agrarian stress: The potential for upscaling small-scale water storage in Nepal. IWMI Research Report 159. Colombo, Sri Lanka: International Water Management Institute 2014). We say renewed interest because, as we have seen there is a very large literature (both for Nepal and internationally) on natural resource development from the 1970 through to the current time which explicitly looks as such things. It is significant to see it now gain 'traction' in hydropower policy debates in Nepal. Surprisingly, conventional macroeconomic Leontief analysis has not figured highly in these debates, although it systematically looks at many of the issues raised by water/food/energy nexus analysis. Leontief input output models, by focusing on intersector linkages facilitates the analysis of the role of capital goods in economic change.

102.Biggs, S., Sharma, A., Uprety, R. and Justice, S (2017) Rural Change in the Kosi River Basin: A capital goods perspective. Paper for the Third International Conference on Bihar and Jharkhand: Shared History to Shared Vision, March 24-27, 2017. Asian Development Research Institute (ADRI), Patna, Bihar.

103.Shrestha, RSManaging Risks in Private Sector Hydro Development in Nepal. HRW Journal, November 2000. 